\title{
JUSTIFICATION OF RFID IMPLEMENTATION. A CASE STUDY OF WHITE GOODS MANUFACTURER
}

\author{
Bartlomiej Gladysz, Katarzyna Nalepa, Krzysztof Santarek \\ Warsaw University of Technology, Institute of Production Systems Organization, Poland \\ Corresponding author: \\ Bartlomiej Gladysz \\ Warsaw University of Technology \\ Institute of Production Systems Organization \\ Narbutta 86, 02-524 Warsaw, Poland \\ phone: (+48) 22 234-81-26 \\ e-mail: b.gladysz@wip.pw.edu.pl
}

Received: 12 October 2016 Accepted: 12 October 2017

\begin{abstract}
Radio Frequency Identification (RFID) is a rapidly emerging technology with a wide range of impact and still not fully exploited potential applications. The impact of RFID is not limited to the area of its direct application. There are many possible benefits to be gained from RFID application, but it must be preceded with careful analysis as its implementation is not always reasonable. A new method for an assessment of RFID technology was presented and explained on the case of a white goods manufacturer. There was a lack of such a method allowing for relatively quick and flexible assessment, which is important for decision makers, who do not want to become involved in very sophisticated and time-consuming analysis at the early stage of decision making. The method supports early phases of decision making related to RFID implementation. Conclusions derived from the analysis of the case study confirmed that the method applied allows for rationalizing decision making and answers whether RFID could generate strategic advantage, in which area RFID should be applied, how RFIDsupported processes will be executed and what benefits would be expected. previous papers focused only on answering specific questions from the above list, without showing a holistic approach. the approach to answer questions about execution of processes and benefits was not considered earlier at all. The paper illustrates details of using a new method of an assessment of RFID technology (ART) using a real industrial example.
\end{abstract}

KEYWORDS

technology assessment, RFID, SCOR, TOPSIS, fuzzy sets.

\section{Introduction}

Many companies are looking for new sources of competitive advantage and the ability to improve operational efficiency by streamlining logistics processes within the enterprise and supply chains. This usually requires a re-engineering of existing logistics processes including the application of new concepts and tools to support the flow of materials and information, and to control them. In these activities identification technologies, including RFID - Radio Frequency Identification are of great importance.

Every time when radio frequencies (RF) are used to identify and/or locate a tagged object, authors use the term "RFID". An RFID system consists of hardware and software components. Hardware com- ponents are those used to tag objects (e.g. RFID tags, labels, inlays) and readers with antennas used to identify tags (tagged objects). A unique identifier encoded in the RFID tag is read by a reader with antennas. Software components are those used to manage, control, maintain hardware components and collect, filter, group readouts into transactions (depicting business logic), integrate, exchange data with enterprise back-end systems.

There exists extensive literature available describing in details the physics, standards related to radio waves and communication protocols, and applications of RFID [1-4]. RFID is a dynamically developing and innovative technology, which is reflected in the rapidly growing number of its applications $[5,6]$. RFID applications are not limited to predefined use 
cases and are not simply a more effective replacement of bar codes. Kevin Ashton, a co-founder of the AutoID Center at the Massachusetts Institute of Technology said: "Calling RFID a radio bar code is like calling a car a motorized horse" [7]. RFID offers new ways of execution of processes and it enables dramatic changes in business processes. Processes can be performed in a way previously impossible due to technology limitations.

Several authors reported on details of RFID deployments and benefits achieved in many areas, e.g. production logistics, warehousing and external supply chains. There are also many difficulties reported related to return on investment calculations and high costs of RFID implementation [8-10]. This means that RFID implementation needs to be preceded by detailed pre-investment analysis (feasibility study). RFID could eliminate inefficiencies and delays in communication and identification processes, but its applications may not bring the expected benefits and be economically ineffective [11].

All considerations bring to a conclusion that RFID implementation needs to be preceded by detailed analysis, what is strongly recommended in particular for every innovative technology with a wide range of impact of which one example is RFID.

\section{A method for assessment of RFID technology}

Identification of objects is the starting point of information flow in the supply chain. Therefore, it is essential/important from the point of view of IT, organizational and economic aspects of processes in supply chains, which are of particular importance in manufacturing companies. It is also an essential/important part of communication processes in the supply chain, especially in terms of reliable encoding and decoding an object's data.

Proper identification performance of processes allows for elimination of disruptions impacting communication and stronger integration of object flow with information flow. Identification of objects and information flow performed manually are time-consuming and prone to errors, so in an industrial environment, technology is commonly used to automate identification tasks. Radio frequency identification is an example of such a technology. It is innovative and dynamically developing, especially in Poland [33, 34].

A review of literature on design, implementation and evaluation of RFID solutions for logistics processes was conducted and results were published e.g. by $[12-16]$. There were also papers found on
RFID-based business models and deployment methods $[36,37]$, but those papers do not address issues related with creation of strategic advantage on a basis of RFID implementation. However, there were no papers found about strategic decisions indicating if RFID should be considered, which processes should be improved and how and what be the expected effects of changes. There are several approaches allowing for evaluation of specific solutions, classification of benefits in different areas of RFID application (especially in supply chains), identification and assessment of qualitative benefits and measurable factors, RFID evaluation in terms of characteristics of specific economies, branches and markets. All authors conclude that RFID is the technology that eliminates numerous dysfunctions of communication processes in supply chains and is implemented successfully for logistics processes in many branches. At the same time authors emphasize the need for detailed preimplementation analysis and calculations of investment profitability. The literature does not include research results or synthetic descriptions of simple and easy-to-use methods to solve problems related to implementation of RFID on consecutive levels of a company strategy, tactics, operations and evaluation. The problem if RFID should be applied is very broad, so the top-bottom approach was proposed, starting from general (strategic module) problems and finishing with evaluation of economic effectiveness (evaluation module). In between, there is a gap which is filled by scoping activities to answer where and how to use RFID, i.e. tactics and operational modules. Proposed approach is applicable for companies not having RFID in their portfolio and having doubts if, where and how to apply RFID. It is a tool to mitigate those uncertainties.

Assessment of RFID Technology (ART) is a method used to support and to rationalize decision making during consideration of possible application of RFID and in early phases of RFID application (see Figs. 1 and 2). Its positive outcome gives a green light to assigning resources to detailed analysis. It is also an assumption for further detailed economic analysis and system engineering. ART output is a ranking of processes based on RFID-based improvement potential. Outputs of the method are inputs for further economic effectiveness analysis (e.g. ROI). Areas of ART application are both internal and external supply chains. It uses a holistic, synthetic and hierarchical top-down approach, but reference models for logistics are usually needed. The ART hierarchical approach is a sequence of modules: from strategy (ART-S) through tactics (ART-T) and operations (ART-O) to evaluation (ART-E). 
Management and Production Engineering Review

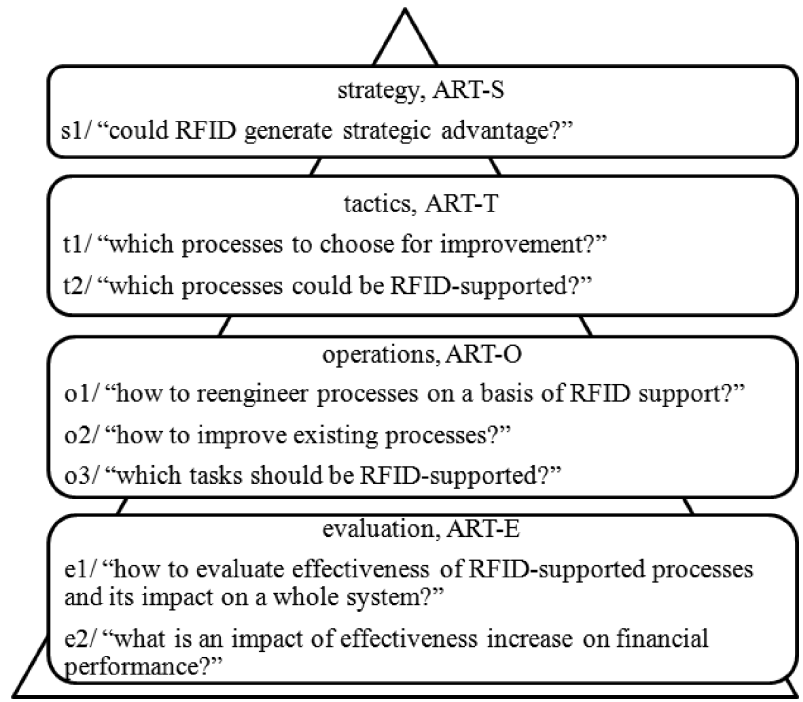

Fig. 1. Research questions and structure of ART $[12,15]$.
Solving decision problems is supported by specific tools:

- technology portfolio methods for strategic evaluation of RFID [17, 18] - at ART-S,

- reference model [19] of business processes (or company specific model, if available and preferred) for "as-is" modelling and a base for defining possible applications of RFID - ART-T,

- multiple attribute group decision making (MADM) [20, 21] based on expert linguistic evaluations of alternatives for ranking of possible RFID applications for logistics processes of a company - ART-T,

- linguistic scales for expert evaluations [20, 22] and fuzzy sets for mathematical representation of scales $[23,24]$ - ART-S, ART-T.

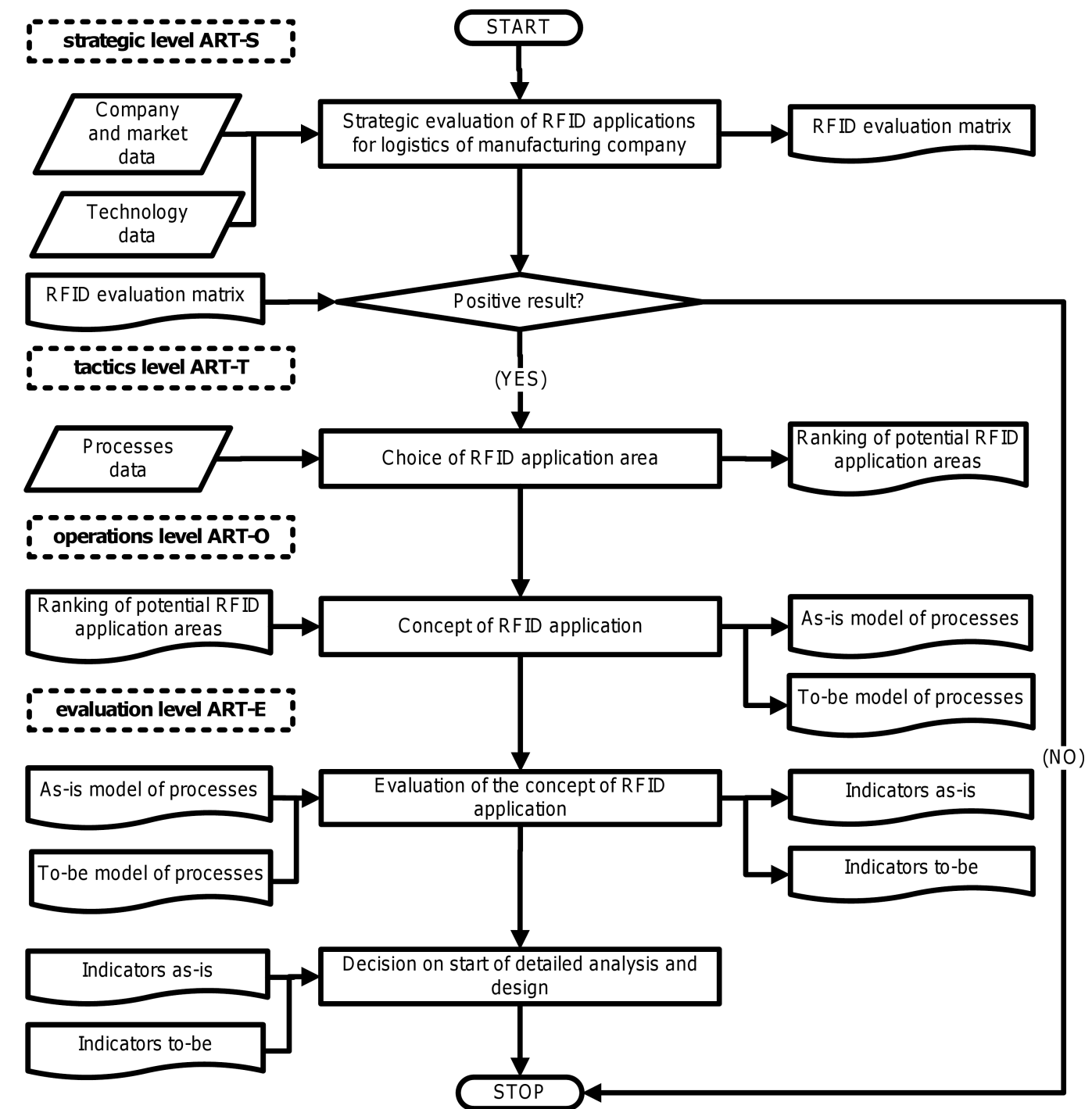

Fig. 2. General algorithm of ART [12, 15]. 
Objective alternatives are uncertain and decision making is based on human thought, which is fuzzy in its nature. The problem is complex, so linguistics scales are used for qualitative expert evaluation. The decision environment cannot be clearly defined, especially at the early phases of alternatives evaluation. At this stage information is unquantifiable and approximate value is tolerable so linguistics scales are a proper means to be used [22].

Linguistic evaluations are uncertain and fuzzy, so fuzzy sets were used as representation of linguistic scales.

Specifically, the Pfeiffer matrix is proposed because of its proven usefulness for evaluation of innovative technologies [26]. The matrix has two dimensions: external and internal. Two main attributes of technology are evaluated using the Pfeiffer matrix: technology attractiveness and resources' strength. These main attributes are then split into 8 lowestlevel criteria (see Fig. 3). Lowest-level criteria are used by experts to conduct detailed assessment using linguistic scale (see Table 1).

Linguistic scale and fuzzy numbers were chosen according to expert method due to the lack of data to use more sophisticated methods [33] and are consensus of authors' discussion with RFID practitioners. Subsequently, the obtained results are aggregated and defuzzified to determine ETA (Evaluation of Technology Attractiveness) and ERS (Evaluation of Resources' Strength - company potential) crisp values. The same linguistic scale is used in the ART$\mathrm{T}$ module. More detailed analysis and description of tools and methods implemented within all four modules of the ART method and their applications were presented by $[12-16]$.

We use multiple attribute decision making (MADM) that is "making preference decisions (such as evaluation, prioritization, selection) over the available alternatives that are characterized by multiple, usually conflicting, attributes" [21].

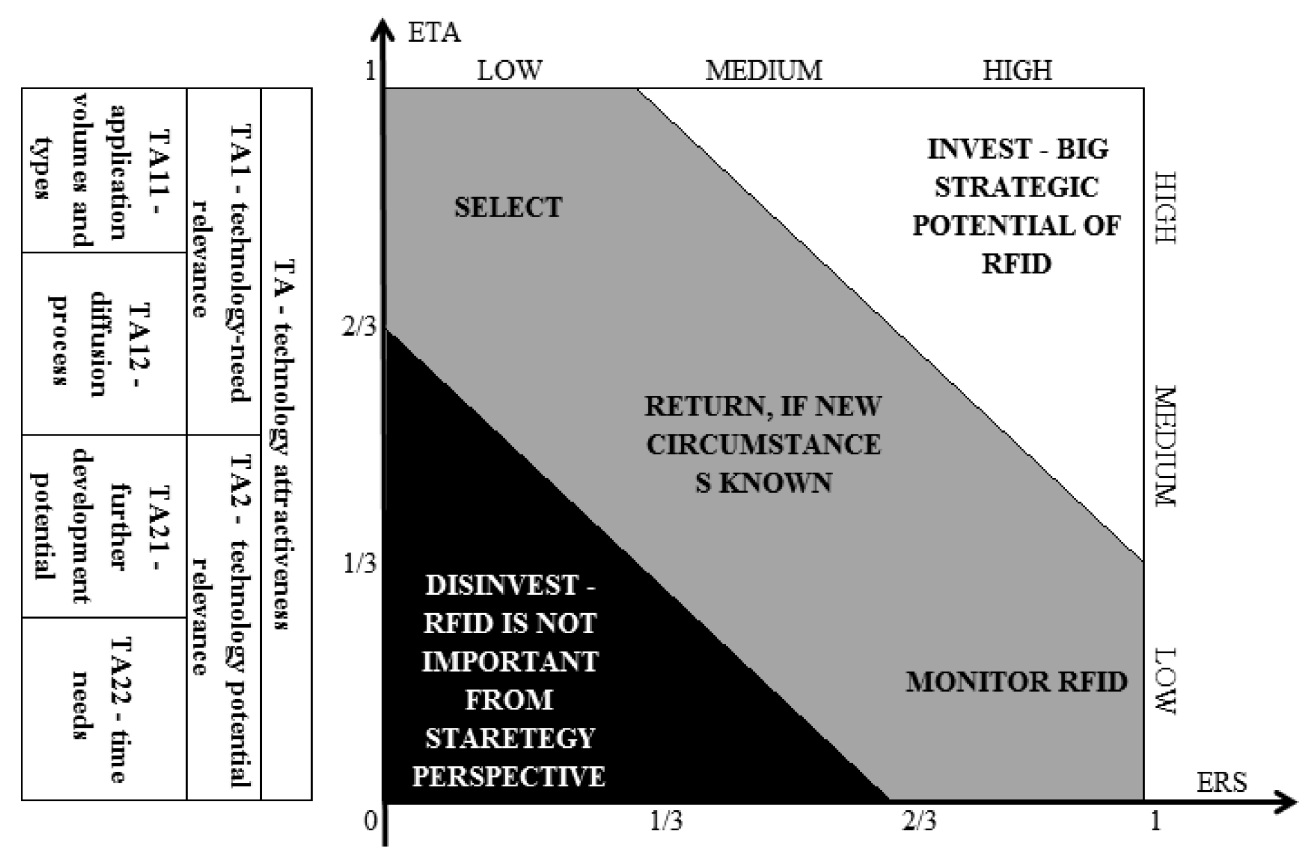

\begin{tabular}{|c|c|c|c|}
\hline \multicolumn{3}{|c|}{ RS - resources' strength } \\
\hline RS1 - financial resources & \multicolumn{2}{c|}{ RS2 - know-how } \\
\hline RS11 - budget & $\begin{array}{c}\text { SZ12 - } \\
\text { consistency of } \\
\text { budget }\end{array}$ & $\begin{array}{c}\text { RS21 - level of } \\
\text { know-how }\end{array}$ & $\begin{array}{c}\text { RS22 - } \\
\text { stability of } \\
\text { know-how }\end{array}$ \\
\hline
\end{tabular}

Fig. 3. Pfeiffer matrix - criteria and recommendations based on [25, 26].

Table 1

Fuzzy sets representation.

\begin{tabular}{c|c|c|c|c|c}
\hline Linguistic variables & Very Low $(\mathrm{VL})$ & Low $(\mathrm{L})$ & Medium $(\mathrm{M})$ & High $(\mathrm{H})$ & Very High $($ VH) \\
\hline Triangular fuzzy number $(\mathrm{a} ; \mathrm{b} ; \mathrm{c})$ & $(0 ; 0 ; 0.25)$ & $(0 ; 0.25 ; 0.5)$ & $(0.25 ; 0.5 ; 0.75)$ & $(0.5 ; 0.75 ; 1)$ & $(0.75 ; 1 ; 1)$ \\
\hline
\end{tabular}




\section{Case study}

\section{Short description of the company}

The analyzed company is one of the largest European manufacturers and distributors of white goods, with a turnover in excess of $€ 2.7$ billion and almost 13 million large home appliances sold in 2013. Currently the company has eight different production facilities across Europe that serve major markets like Italy, the United Kingdom, Portugal and Russia. The product range is growing year over year, resulting in new product launches and more innovative product versions.

The assembly process is typical, so interchangeable parts are mounted to the semi-finished goods and transported between work stations according to the sequence of operations.

Today, the household appliances business is characterized by a high level of competitiveness. Faster technological development, shorter product life cycle and intense global competition force the company to seek new ways for improving operating efficiency across the entire supply chain.

For the purpose of this paper, one of the company group's production locations was investigated in depth in order to justify the relevance of RFID implementation. The field study was executed in the manufacturing site specialized in production of washing machines. Annual production volume is almost 2 million units consisting of 300 different models (types). Every model is assembled from hundreds of parts. It is calculated that to fulfil yearly demand over 60 million raw and semi-parts have to be delivered to the plant. The huge complexity of the product and lack of standardized process of objects identification make the internal logistics processes difficult to manage. This results in poor planning and sometimes even leads to production downtimes due to missing components or late supply of the assembly line.

The case study explains details of ART method and it is focused on answering whether RFID should be considered for the company, which processes should be chosen to improve and what will be effects of proposed RFID application. Therefore, it is focused on answers to all the questions shown in Fig. 1.

\section{Strategic assessment of RFID technology implementation at ART-S level}

Concerning the presented method, two independent experts (an internal expert and external RFID consultant) were engaged in strategic evaluation of RFID implementation in the company. All criteria (see section A method for assessment of RFID technology) have been captured in the questionnaire (see Fig. 4, where VH - very high; $\mathrm{H}$ - high; $\mathrm{M}$ - middle; $\mathrm{L}$ - low; VL - very low).

Based on the research conducted and experts' opinion, the crisp values according to Yager formula [27] were computed and aggregated results were positioned on the Pfeiffer matrix [17, 18]. Strategic assessment of RFID was conducted using criteria and an approach proposed by [16].

\begin{tabular}{|c|c|c|c|c|c|c|c|c|c|c|c|c|}
\hline 1 & \multicolumn{12}{|c|}{ ART-S } \\
\hline \multirow[t]{2}{*}{2} & & Attribute & \multicolumn{5}{|c|}{ (I) Internal Expert } & \multicolumn{5}{|c|}{ (E) External RFID Expert } \\
\hline & \multicolumn{2}{|c|}{ Technology Atractiveness } & Mark & \multicolumn{3}{|c|}{$\begin{array}{l}\text { Average Fuzzy } \\
\text { Sets }\end{array}$} & $\begin{array}{l}\text { Crisp } \\
\text { Value }\end{array}$ & Mark & \multicolumn{3}{|c|}{$\begin{array}{l}\text { Average Fuzzy } \\
\text { Sets }\end{array}$} & $\begin{array}{l}\text { Crisp } \\
\text { Value }\end{array}$ \\
\hline 4 & \multirow[t]{7}{*}{$\begin{array}{l}\text { Applications } \\
\text { volumes, types }\end{array}$} & $\begin{array}{l}\text { Does Company Group use RFID } \\
\text { Technology? }\end{array}$ & VL & \multirow[t]{8}{*}{0.49} & \multirow[t]{8}{*}{0.71} & \multirow[t]{8}{*}{0.87} & \multirow[t]{9}{*}{0.7} & VL & \multirow[t]{9}{*}{0.47} & \multirow[t]{9}{*}{0.69} & \multirow[t]{9}{*}{0.82} & \multirow[t]{9}{*}{0.67} \\
\hline 5 & & $\begin{array}{l}\text { Do household appliances producers use } \\
\text { RFID Technology? }\end{array}$ & $\mathrm{H}$ & & & & & VH & & & & \\
\hline 6 & & $\begin{array}{l}\text { Could RFID implementation open new } \\
\text { markets? }\end{array}$ & $\mathrm{H}$ & & & & & VH & & & & \\
\hline 7 & & $\begin{array}{l}\text { Will RFID Technology strenght the } \\
\text { company position on the market? }\end{array}$ & $\mathrm{H}$ & & & & & VH & & & & \\
\hline 8 & & $\begin{array}{l}\text { Will RFID Technology influance on the } \\
\text { company comeptitive advantage? }\end{array}$ & VH & & & & & VH & & & & \\
\hline 9 & & $\begin{array}{l}\text { Could RFID result in increase of market } \\
\text { share? }\end{array}$ & $\mathrm{H}$ & & & & & $\mathrm{VH}$ & & & & \\
\hline 10 & & $\begin{array}{l}\text { Are logistics processes critical for } \\
\text { Indesit company? }\end{array}$ & VH & & & & & VH & & & & \\
\hline \multirow{2}{*}{\multicolumn{2}{|c|}{$\begin{array}{l}\text { Diffusion process } \\
\text { potential }\end{array}$}} & $\begin{array}{l}\text { What is the common position of strategic } \\
\text { company's stakeholders in relation to } \\
\text { RFID? }\end{array}$ & $\mathrm{VH}$ & & & & & $\mathrm{H}$ & & & & \\
\hline & & वиतra & & & & & & & & & & \\
\hline
\end{tabular}

Fig. 4. An excerpt of ART-S questionnaire. 
The obtained results (see Fig. 5) are allocated on the border between two adjacent areas which represent recommendations: to invest selectively/to monitor or to invest (in RFID technology). Therefore there are serious reasons for further investigation of investment opportunities in RFID technology, which can be accomplished using next module of ART method.

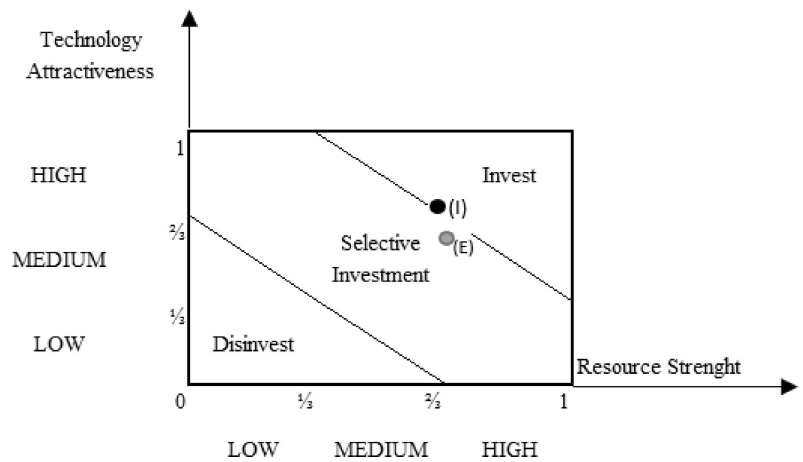

Fig. 5. Aggregated results of ART-S module assessment made by internal (I) and external consultant (E).

\section{Tactical assessment of RFID technology at ART-T level}

The tactical assessment of RFID technology (ART-T) is aimed at definition, evaluation, ranking and selection of processes for further improvement. Definitions of alternative processes (see Tables 2-4) that could be potentially RFID supported were based on the first level of SCOR model [19] and given for consideration to a group of three decision makers from the company.

Defined RFID applications were evaluated using the following criteria: potential of labour effectiveness improvement (C1), inventory levels (C2), problems with identification accuracy (C3), process importance - weight (C4), organizational barriers (C5) and technological barriers (C7) as well as estimated costs (C6) of RFID implementation. Each criterion (see Table 5) has its own agreed weight that reflects its importance in a set of fuzzy numbers. The decision makers performed the evaluation of alternative areas with the help of linguistic variables (see Table 1).

Table 2

SCOR-based definitions of assessed alternatives - source (S) process.

\begin{tabular}{c|l}
\hline Description & $\begin{array}{l}\text { Activities associated with ordering and receipt of goods, including purchase } \\
\text { orders, scheduling deliveries, order receiving, shipment validation and storage }\end{array}$ \\
\hline Tagged objects & Logistics unit (case/pallet) \\
\hline Tag application point & Supplier's site \\
\hline Main expected benefits & $\begin{array}{l}\text { RFID tag is applied at supplier's site at the packaging stage (case), then the } \\
\text { delivery is transported to the company plant. During the process of unloading, } \\
\text { the pallets with the cases pass through a gate equipped with RFID reader and } \\
\text { the information contained in the tag is automatically acquired to the system }\end{array}$ \\
\hline $\begin{array}{l}\text { Acceleration and automation of human work in the warehouse (goods receiv- } \\
\text { ing area), elimination of frequent data errors, real time data capture, reduction } \\
\text { of errors in logistics documentation. }\end{array}$ \\
\hline
\end{tabular}

Table 3

SCOR-based definitions of assessed alternatives - make (M) process

\begin{tabular}{c|l}
\hline \multicolumn{1}{c|}{ Description } & $\begin{array}{l}\text { Activities include conversion of materials, maintenance and facility manage- } \\
\text { ment. }\end{array}$ \\
\hline Tagged objects & Trade items \\
\hline Tag application point & Production line (Cabinet line) \\
\hline Scenario for RFID - supported process & $\begin{array}{l}\text { An RFID tag is attached to each steel sheet making up the main body of } \\
\text { the washing machine. The unit is identified throughout the manufacturing } \\
\text { process. The planning section is informed about work in progress, semi- fin- } \\
\text { ished materials used in the production, and the status of the production order } \\
\text { is automatically captured. }\end{array}$ \\
\hline Main expected benefits & $\begin{array}{l}\text { Automation of WIP identification, acceleration of real time data for planning } \\
\text { section, decreased level of WIP, real time control of production order }\end{array}$ \\
\hline
\end{tabular}


Table 4

SCOR-based definitions of assessed alternatives - deliver (D) process.

\begin{tabular}{c|l}
\hline Description & $\begin{array}{l}\text { Activities combining customer order creation, maintenance and fulfilment, } \\
\text { scheduling order deliveries, pick, pack, transportation, and invoicing the cus- } \\
\text { tomer }\end{array}$ \\
\hline Tagged objects & Trade item \\
\hline Tag application point & Production line (Packaging station) \\
\hline Scenario for RFID - supported process & $\begin{array}{l}\text { An RFID tag is attached to the finished good and transferred to the ware- } \\
\text { house. The actual stocks of finished goods are updated in the system in real } \\
\text { time. When the customer order is placed and completed, the level of inventory } \\
\text { is updated in the system. }\end{array}$ \\
\hline Main expected benefits & $\begin{array}{l}\text { Automation of FG stocks, acceleration of order complementation, possibility } \\
\text { of tracking deliveries to retailers }\end{array}$ \\
\hline
\end{tabular}

Results of evaluation are presented in the Table 6 and were input for fuzzy TOPSIS method.

The general definition of possible RFID applications, evaluation criteria for ART-T modules, fuzzy group TOPSIS calculations were given by [14]. In accordance with the TOPSIS algorithm [20, 21, 27], the fuzzy decision matrix (see Table 6) was normalized and multiplied by the weight vector (see Table 5). Afterwards the distance from the positive ideal solution $\left(d_{i}^{+}\right)$and its distance from the fuzzy negative ideal solution $\left(d_{i}^{-}\right)$were calculated. The ranking is presented on the Fig. 6. Based on the closeness index values $\left(C_{i}\right)$, the ranking of alternatives among the most promising is Source, Make, Deliver.

Table 5

List of evaluation criteria and their weights.

\begin{tabular}{c|l|c}
\hline C1. & $\begin{array}{l}\text { Potential to improve labour effectiveness; The need to accelerate raw material, work in progress, finished } \\
\text { goods identification and minimize of labour. }\end{array}$ & VH \\
\hline C2. & $\begin{array}{l}\text { Inventory levels; The need to decrease inventory level, improve inventory transparency and reliability of } \\
\text { stock data. }\end{array}$ & H \\
\hline C3. & $\begin{array}{l}\text { Problems with accuracy; The need to eliminate frequent data errors occurring during receiving or picking } \\
\text { goods. }\end{array}$ & VH \\
\hline C4. & Process weight; The importance of the processes along the supply chain. & M \\
\hline C5. & $\begin{array}{l}\text { Organizational barriers; The occurrence of organizational barriers that could be a constraint for RFID } \\
\text { implementation. }\end{array}$ & $\mathbf{H}$ \\
\hline C6. & Estimated cost; The level of estimated cost needed for RFID implementation. & VH \\
\hline C7. & Technological barriers; Technological barriers that could be a constraint for RFID implementation. & $\mathbf{H}$ \\
\hline
\end{tabular}

Table 6

Decision matrix for ART-T.

\begin{tabular}{c|c|c|c|c|c|c|c|c}
\hline \multirow{2}{*}{ Decision makers } & \multirow{2}{*}{ Alter-natives } & \multicolumn{7}{|c}{ Criteria } \\
\cline { 3 - 9 } & & $\mathrm{C} 1$ & $\mathrm{C} 2$ & $\mathrm{C} 3$ & $\mathrm{C} 4$ & $\mathrm{C} 5$ & $\mathrm{C} 6$ & $\mathrm{C} 7$ \\
\hline \multirow{3}{*}{ DM1 } & Source & $\mathrm{VH}$ & $\mathrm{VH}$ & $\mathrm{VH}$ & $\mathrm{VH}$ & $\mathrm{VL}$ & $\mathrm{M}$ & $\mathrm{L}$ \\
\cline { 2 - 9 } & Make & $\mathrm{L}$ & $\mathrm{M}$ & $\mathrm{L}$ & $\mathrm{VH}$ & $\mathrm{M}$ & $\mathrm{H}$ & $\mathrm{M}$ \\
\cline { 2 - 9 } & Deliver & $\mathrm{H}$ & $\mathrm{H}$ & $\mathrm{L}$ & $\mathrm{H}$ & $\mathrm{VL}$ & $\mathrm{M}$ & $\mathrm{L}$ \\
\hline \multirow{3}{*}{$\mathrm{DM} 2$} & Source & $\mathrm{VH}$ & $\mathrm{H}$ & $\mathrm{VH}$ & $\mathrm{VH}$ & $\mathrm{L}$ & $\mathrm{L}$ & $\mathrm{VL}$ \\
\cline { 2 - 9 } & Make & $\mathrm{M}$ & $\mathrm{L}$ & $\mathrm{L}$ & $\mathrm{VH}$ & $\mathrm{H}$ & $\mathrm{M}$ & $\mathrm{L}$ \\
\cline { 2 - 9 } & Deliver & $\mathrm{M}$ & $\mathrm{M}$ & $\mathrm{VL}$ & $\mathrm{VH}$ & $\mathrm{L}$ & $\mathrm{H}$ & $\mathrm{VL}$ \\
\hline \multirow{3}{*}{$\mathrm{DM} 3$} & Source & $\mathrm{VH}$ & $\mathrm{VH}$ & $\mathrm{VH}$ & $\mathrm{VH}$ & $\mathrm{L}$ & $\mathrm{M}$ & $\mathrm{M}$ \\
\cline { 2 - 9 } & Make & $\mathrm{M}$ & $\mathrm{M}$ & $\mathrm{L}$ & $\mathrm{VH}$ & $\mathrm{L}$ & $\mathrm{H}$ & $\mathrm{H}$ \\
\cline { 2 - 9 } & Deliver & $\mathrm{H}$ & $\mathrm{H}$ & $\mathrm{VL}$ & $\mathrm{H}$ & $\mathrm{L}$ & $\mathrm{M}$ & $\mathrm{M}$ \\
\hline
\end{tabular}




\begin{tabular}{cccc} 
Criteria & SOURCE & M.AKE & DELIVER \\
\hline$d_{i}^{+}$ & 3.39 & 3.86 & 4.58 \\
$d_{i}^{-}$ & 3.85 & 3.35 & 2.75 \\
$C_{i}$ & 0.53 & 0.46 & 0.37 \\
\hline
\end{tabular}

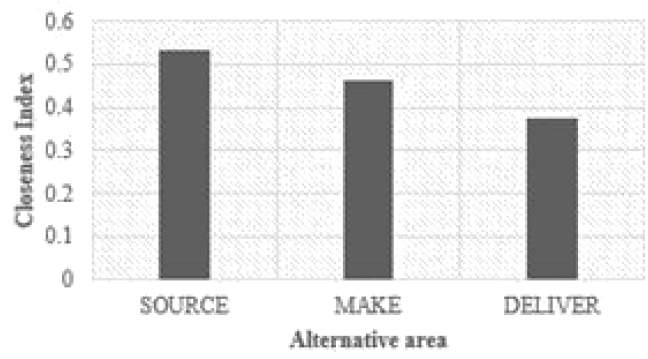

Alternative area

Fig. 6. Final results of ART-T module.

\section{Operational assessment of RFID technology at ART-O level}

Figure 7 depicts the "as-is" model and current flow of processes in the raw materials and semifinished goods warehouse. The process starts after the truck arrives at the plant. The entire process is handled manually and the FIFO (first in first out) rule is applied. Each truck has to wait for available resources to handle the delivery. After the truck is parked at the dock, the transportation documents (CMR) are verified and unloading process is continued. Each pallet is checked and verified against the ordered quantity. If delivered goods are not in line with CMR, then its correction is issued and goods are accepted. The goods received receipt is delivered to logistics administration, and records in the system are updated. The identification of all received goods is executed manually. There is no available form of standardized object identification in place. Goods unloading and receiving in the raw materials and semi-finished goods warehouse is performed on the basis of transportation documents. This model requires extensive human resources, is time-consuming and results in frequent data errors. All these factors are reflected in high operational cost.

As the result of ART-T recommendation, the "tobe" model was developed. The future flow of processes is presented on the Fig. 8. RFID will significantly simplify processes currently performed in Source area. Pallet boxes are scanned at the entrance to the warehouse, and this will be done during unloading pallets from the truck. Data related to each box are collected into the ERP database. The RFID system allows for eliminating many non-added value activities, e.g. checking the content of the pallet and counting every box delivered, confirmation of receiving goods and issuing the correction in case of discrepancies, delivering documents to logistics administration and manual entry of documents into the system.

Implementation of RFID technology is a collaborative process involving both supplier and receiver. Therefore, to simplify the complex logistics flow from all of the company's suppliers and facilitate the process of object identification in the warehouse, every logistic unit needs to be labelled with RFID tags. According to GS1 standards, each logistics unit will be identified using Electronic Product Code [2830], a universal identifier for specific physical objects. Concerning the field of the study, the GS1 identification key for logistics units is Serial Shipping Container Code (SSCC) [29]. The operational flow of RFIDrelated processes will begin at the point of tagging objects. From the point of view of RFID technology implementation in the company, each logistics unit, either a case or a pallet, will have to be tagged at the supplier plant. Based on experts' recommendation, passive UHF RFID tags and EPC Class1 Gen.2 standard [28] will be used.

The first reason for this is that the passive tags do not have their own sources of power, due to which their price is lower. Secondly, ultra-high frequency enables long reading distances, relevant for the warehouse case. Thirdly, UHF and EPC Class1 Gen.2 are widely adopted for logistics purposes by many companies all over the world. The interrogation zone where the tags are going to be read should be set up close to the unloading docks. A gate equipped with an RFID reader will additionally ensure that all pallets delivered to the warehouse are read at the entrance of an unloading zone. The benefits of the RFID system are predicted in the areas of transporting real time, standardized and serialized data through their integration with existing ERP (enterprise resource planning) system. The objective in the examined business case was to design and develop a solution that could combine an RFID and ERP systems. The implementation of such solution will make sense if it is capable of easy transformation of data into information useful for supporting all logistics functions. The company uses the ERP system - SAP/R3 - on a daily basis. RFID can be easily incorporated through SAP Auto ID Infrastructure (AII) solution. SAP AII is a middleware system that receives data from RFID readers, and then integrates data acquired from the RFID tags directly into the business application. The proposed solution combines a backend ERP system, RFID devices and user interface.

Volume $8 \bullet$ Number $4 \bullet$ December 2017 


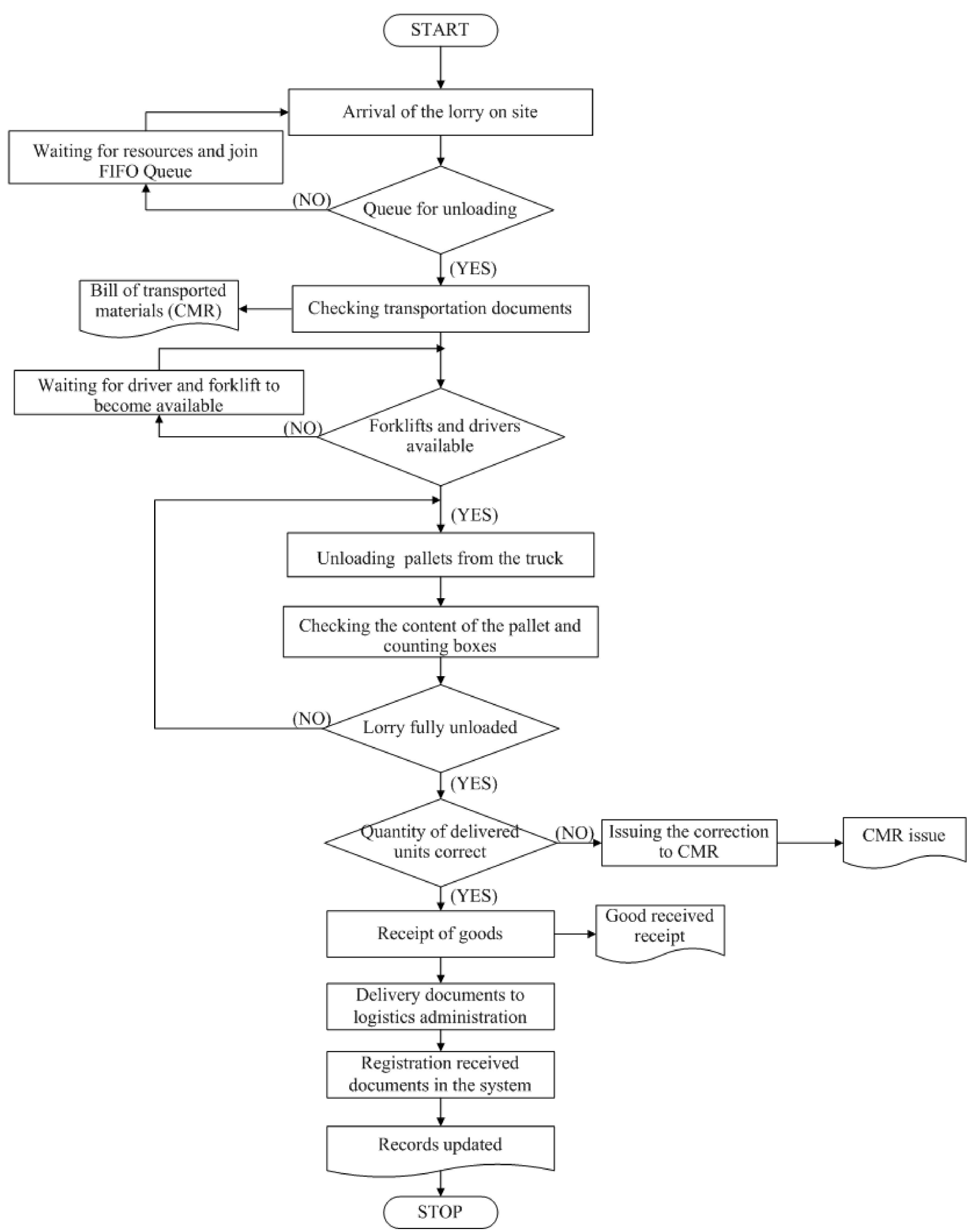

Fig. 7. As-is model of Source area. 


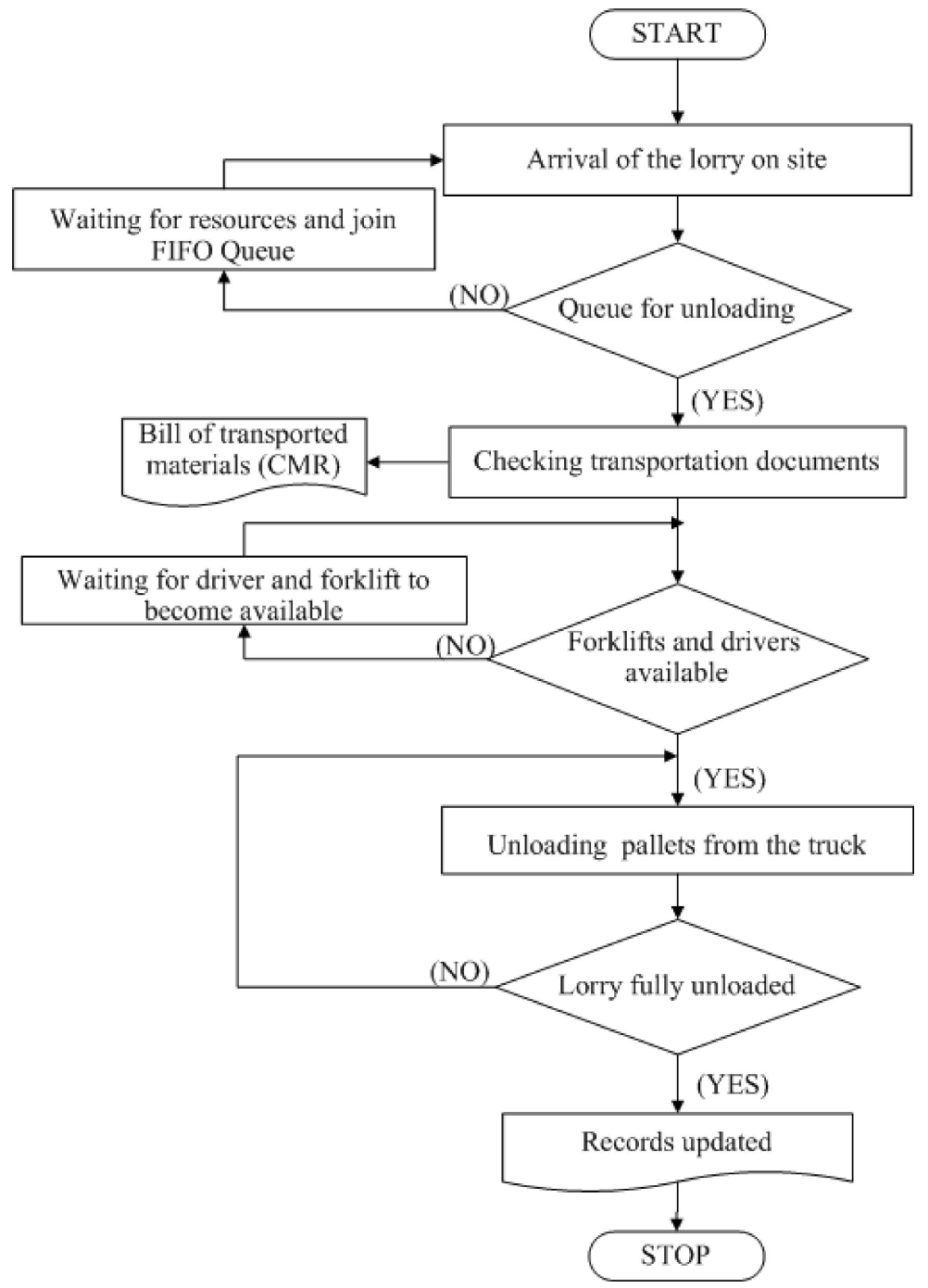

Fig. 8. To-be model of Source area.

Data exchange between the supplier and the company is be based on an Advance Shipping Notice (ASN) [31], which contains the SSCC number, delivery date and quantities of materials. The ERP system displays the ASN data and registers EPC numbers in AII. SAP II Infrastructure receives raw data and converts them into business information. At this stage the data collected in the tag is compared with the former ASN, and the post goods receipt is created and sent back to the supplier.

In the RFID-supported "to-be" model, incoming shipments are swiftly identified with almost no paperwork, less human work and high accuracy.

\section{Evaluation of analyzed solution at ART-E level}

Deployment of RFID Technology is a business decision and cost-benefit analysis and is a key compo- nent to make go or no-go decision. RFID technology can offer five primary kinds of benefits including: lower operating costs, increase of revenue, lower overheads cost, reduced inventory capital cost and lead time reduction [32]. RFID in a warehouse enables reducing the number of incorrect manual counts and unreported stocks. Automated reconciliation of received goods enables an increase of work productivity and will lead to a decrease of overheads and operating expenses. Improvement of stock data accessibility and elimination of discrepancies will significantly improve visibility of inventories and allow reducing inventory capital. Real data capture will make safety stocks easier to manage and to reduce the probability of stocks out respectively. RFID also results in intangible benefits, e.g. an increase of organizational transparency, more accurate and faster access to data for timely decisions and strategic planning, decrease of time and effort needed for data en- 
try, better control and increase of resource utilization.

Deploying RFID system involves more than just buying and installing hardware components. The cost of RFID implementation depends on the application, the size and area of the installation, the type of system and many other factors, such as integration with existing systems and training of employees. To get business value from collected data the company needs to invest in middleware to filter RFID data. It may also need to hire a systems integrator and upgrade the existing ERP system. Hardware refers to installation of the door dock readers and adjustment the network and power infrastructure. Based on the observation processes taking place in the warehouse, the average times of performed activities were collected, and the associated unit labour costs were calculated in proportion to the monthly salary of a stock keeper $(1000 €)$. RFID allows for eliminating the labour intensive processes of unloading and manually handled object identification. These operations were accordingly excluded from the to-be model (see Table 7).

RFID results in eliminating the majority of timeconsuming activities due to elimination of manually performed work and a decrease in the workforce required (see Table 8).

RFID provides a significant improvement of existing process effectiveness in the Source area. Justification of RFID initiative is based on four key performance indicators commonly applied in the warehouse (see Table 9). There is a meaningful increase in work efficiency and work intensity. Regarding workforce analysis, the substantial reduction of the workforce required has a very large impact on direct labor costs.

Table 7

Times and costs of activities in Source area.

\begin{tabular}{|c|c|c|c|c|c|c|c|c|}
\hline & \multicolumn{4}{|c|}{ As-is } & \multicolumn{4}{|c|}{ To-be } \\
\hline Pallets & \multicolumn{2}{|c|}{ Combined } & \multicolumn{2}{|c|}{ Homogenous } & \multicolumn{2}{|c|}{ Combined } & \multicolumn{2}{|c|}{ Homogenous } \\
\hline Activities in Source area & $\begin{array}{l}\text { Time } \\
{[\mathrm{min}]}\end{array}$ & $\begin{array}{c}\text { Cost } \\
{[€]}\end{array}$ & $\begin{array}{l}\text { Time } \\
{[\mathrm{min}]}\end{array}$ & $\begin{array}{c}\text { Cost } \\
{[€]}\end{array}$ & $\begin{array}{l}\text { Time } \\
{[\mathrm{min}]}\end{array}$ & $\begin{array}{c}\text { Cost } \\
{[€]}\end{array}$ & $\begin{array}{l}\text { Time } \\
{[\mathrm{min}]}\end{array}$ & $\begin{array}{c}\text { Cost } \\
{[€]}\end{array}$ \\
\hline $\begin{array}{l}\text { 1. Verification of the transportation } \\
\text { documents }\end{array}$ & 1.0 & 0.104 & 1.0 & 0.104 & 1.0 & 0.104 & 1.0 & 0.104 \\
\hline 2. Unloading the pallet from the truck & 1.9 & 0.198 & 1.9 & 0.198 & 1.9 & 0.198 & 1.9 & 0.198 \\
\hline $\begin{array}{l}\text { 3. Identification of the content of each } \\
\text { pallet and counting boxes }\end{array}$ & 2.5 & 0.260 & 1.0 & 0.104 & - & - & - & - \\
\hline 4. Confirmation of received delivery & 0.5 & 0.052 & 0.5 & 0.052 & - & - & - & - \\
\hline $\begin{array}{l}\text { 5. Delivery of the documents to logis- } \\
\text { tics administration }\end{array}$ & 0.2 & 0.021 & 0.2 & 0.021 & - & - & - & - \\
\hline $\begin{array}{l}\text { 6. Registration received documenta- } \\
\text { tion and update the records in the sys- } \\
\text { tem }\end{array}$ & 0.2 & 0.021 & 0.2 & 0.021 & - & - & - & - \\
\hline Total & 6.3 & 0.656 & 4.8 & 0.500 & 2.9 & 0.302 & 2.9 & 0.302 \\
\hline
\end{tabular}

Table 8

Workforce analysis.

\begin{tabular}{|c|c|c|c|c|c|}
\hline Analyzed area & As-is & To-be & Analyzed area & As-is & To-be \\
\hline No. of combined pallets unloaded per day & 1188 & 1188 & Unload all pallets $[\mathrm{min}]$ & 11286 & 5742 \\
\hline No. of homogenous pallets unloaded per day & 792 & 792 & Available working time per 1 worker [min] & 450 & 450 \\
\hline Unloading combined pallets [min] & 7484 & 3445 & Number of required workers per day & 25 & 13 \\
\hline Unloading homogenous pallets [min] & 3802 & 2297 & & & \\
\hline
\end{tabular}

Table 9

Comparison effectiveness of processes after RFID implementation in Source area.

\begin{tabular}{l|c|c|c}
\hline Index and units & As-is & To-be & $\%$ of improvement \\
\hline Efficiency [pallets/worker] & 79.2 & 152 & 91.92 \\
\hline Intensity [pallets/hour] & 10.57 & 20.31 & 92.15 \\
\hline Direct labour cost [€/year] & 300000 & 156000 & 48.00 \\
\hline Accuracy of delivery acceptance [\%] & 92.18 & 99 & 7.40 \\
\hline
\end{tabular}


Taking into account a quantitative aspect of RFID implementation, the system should have strong influence on the inventories level. Based on experts' knowledge and experience, the company can achieve even $99 \%$ of accuracy of delivery acceptance. This is equivalent to an over 7\% improvement compared with current performance, enabling better visibility of the stocks in the system and more precise material replenishment and production planning. Better transparency of current stocks leads to lower inventories and more disciplined capital allocation. Exact estimation of these savings requires developing an advanced simulation model. The results obtained lead to the decision about starting an engineering design process of RFID system, which however goes beyond of the scope of this paper.

\section{Conclusions}

The results obtained are promising. At the level of strategic module (ART-S) RFID got high evaluation using Pfeiffer portfolio and a set of specific questions [15]. RFID was then evaluated as a technology that could generate strategic advantage and analysis was extended in the tactics module (ART-T). Possible areas of RFID application were defined and evaluated at this stage of analysis. Those areas were processes (according to SCOR-reference model): Source, Make, Deliver. The Source process was ranked highest and it was chosen as the most promising one. As-is and to-be business models were prepared for the Source process. This part is included in the operations module (ART-O), which clarify how to execute RFID-supported processes. Business models are the basis for performing the first estimation of possible monetary savings and improvements of performance indicators. The last part of the analysis was conducted using the evaluation module (ART-E). The results achieved from this module show significant potential improvement (see Tables 7-9). Therefore, the decision to start detailed engineering design was made. This would be the next step, which goes beyond the scope of the present paper.

The aim of this case study was to present possible approach to initial analysis when considering RFID application. Such holistic approaches answering listed questions (strategic, tactic, operational and evaluation), where not found in literature. Therefore, it is not possible yet to compare ART with other methods. Presented approach allows for holistic assessment. It utilizes several tools, such as technology portfolio matrix, TOPSIS, BPMN. These tools were chosen arbitrary, as their usefulness was document- ed in the reviewed literature. One of further research directions is comparison of selected tools with other possible tools.

Deciding whether to implement the technology with a wide range of impact encounters in praxis specific difficulties. A reliable assessment requires a large amount of detailed data, including those relating to technology implementation projects. This information is usually impossible to obtain without developing a complete (and detailed) design of solutions. The development of such a project is usually expensive, takes time and involves the risk that after completion, the project will show that there are no organizational, economic or technical rationale for implementing a new technology. A solution to this dilemma is the ART method (Assessment of RFID Technology), developed in order to assess the feasibility and advisability of an application of RFID technology in manufacturing companies and supply chains. ART is a method designed particularly to evaluate RFID technology within the framework of a feasibility study, before starting the engineering design. It is an all-purpose and flexible method which can also be used for evaluation of other technologies, especially those with a wide range of impact. In this case, only minor modification of the method will be required. The advantage of ART is also its simplicity. Its use does not require long-term training, it is fast and gives clear recommendations on the need for technology implementation.

The article presents a general concept of the method and explains in detail how to use it on the example of one of the largest European manufacturers and distributors of white goods (household appliances). The ART method in a relatively short period of time allows for a multi-criteria assessment of the feasibility and advisability of the implementation of RFID technology in terms of company's strategic objectives and the required investments, it enables the identification of a process (-es) in which RFID applications can bring the greatest benefits and to assess the magnitude of these benefits.

The described method of an assessment of RFID technology is a result of a PhD thesis submitted by the first author at the Faculty of Production Engineering at the Warsaw University of Technology. The case study was conducted as a part of a MSc thesis prepared by the second author at the same University. Both theses were supervised by the third author.

The work was conducted as a part of research grants "Applications of RFID technologies in manufacturing companies" and "Assessment of technologies with wide range of impact" financed by Warsaw 
University of Technology - Faculty of Production Engineering.

We also thank the company for enabling us to collect data and to conduct detailed research.

\section{References}

[1] Dobkin D.M., The RF in RFID: UHF RFID in Practice, 2nd ed. Oxford: Newnes, 2012.

[2] Finkenzeller K., RFID Handbook, New York (NY): John Wiley \& Sons, 2010

[3] Sweeney P.J. II, RFID for Dummies, Indianapolis: Wiley Publishing, 2010.

[4] Yan L., Zhang Y., Yang L.T., Ning H., The Internet of Things, Boca Ranton (FL): Auerbach Publications, 2008.

[5] IDTechEx. 2015. RFID Knowledge Base, http://tinyurl.com/ovgyuny, accessed: 1 June 2015.

[6] RFID Journal, 2015, http://www.rfidjournal.com, accessed: 1 June 2015.

[7] Roberti M., What Is RFID?, 2011, http://tinyurl.com/z3ojlhv, accessed: 6 January 2016.

[8] Osyk B.A., Vijayaraman B.S., Srinivasan M., Dey A., RFID adoption and implementation in warehousing, Manag. Res. Rev., 35, 10, 904-926, 2012, DOI: 10.1108/01409171211272651.

[9] Sarac A., Absi N., Dauzére-Pérés S., A literature review on the impact of RFID technologies on supply chain management, Int. J. of Prod. Econ., 128, 1, 77-95, 2010, DOI: 10.1016/j.ijpe.2010.07.039.

[10] Zelbst P.J., Green K.W., Sower V.E., Reyes P.M., Impact of RFID on manufacturing effectiveness and efficiency, Int. J. of Oper. \& Prod. Manag., 32, 3, 329-350, 2012, DOI: 10.1108/01443571211212600.

[11] Bendavid Y., Lefebvre E., Lefebvre L.A., Fosso Wamba S., Key performance indicators for the evaluation of RFID-enabled B-to-B e-commerce applications: The Case of a Five-Layer Supply Chain, Inf. Syst. and E-Bus. Manag., 7, 1, 1-20, 2009, DOI: 10.1007/s10257-008-0092-2.

[12] Gladysz B., An assessment of RFID applications in manufacturing companies, Manuf. and Prod. Eng. Review, 6, 4, 33-42, 2015, DOI: 10.1515/mper-20150034 .

[13] Gladysz B., Santarek K., An assessment of technologies with wide range of impact. A case of RFID, Proc. of 6th Int. Conf. on Appl. Hum. Factors and Ergon. (AHFE 2015) and the Affil. Conf., Procedia Manuf., 3, 1966-1973, 2015, DOI: 10.1016/j.promfg.2015.07.242.
[14] Gladysz B., Santarek K., Fuzzy TOPSIS/SCORbased approach in assessment of RFID technology (ART) for logistics of manufacturing companies, Logistics Operations, Supply Chain Management and Sustainability, P. Golinska [Ed.], Springer Int. Publishing, pp. 129-142, 2014, DOI: 10.1007/978-3-31907287-6_9.

[15] Gladysz B., Criteria for strategic evaluation of RFID, Innovations in Manag. and Prod. Eng. (in Polish: Innowacje w Zarządzaniu i Inżynierii Produkcji), Knosala R. [Ed.], Opole (Poland): OWPTZP, pp. 855-866, 2015, http://tinyurl.com/ ppez5mh, accessed: 1 June 2015.

[16] Santarek K., Gladysz B., Strategic evaluation of RFID implementation effects [original in Polish: Ocena strategiczna efektów wdrożenia RFID], Innovations in Management and Production Engineering (in Polish: Innowacje w Zarzadzaniu i Inżynierii Produkcji), Knosala R. [Ed.], Opole (Poland): OWPTZP, pp. 191-202, 2014, http://tinyurl.com/owvmo2n, accessed: 1 June 2015.

[17] Pfeiffer W., Metze G., Schneider W., Amler R., Technologie-Portfolio zum Management strategischer Zukunftgeschäftsfelde, Göttingen: Vandenhoek \& Ruprecht, 1991.

[18] Pleschak F., Sabisch H.. Innovations management, Stuttgart: Schäffer-Poeschel, 1996.

[19] Bolstoff P., Rosenbaum R., Supply Chain Excellence, Saranac Lake (NY): AMACOM, 2011.

[20] Chen S.J., Hwang C.L., Fuzzy Multiple Attribute Decision Making, Berlin: Springer, 1992.

[21] Hwang C.L., Yoon K., Multiple Attribute Decision Making, New York (NY) Springer, 1981.

[22] Xu Z., Linguistic Decision Making: Theory and Methods, Berlin: Springer, 2012.

[23] Zadeh L., Fuzzy sets, Inf. and Control, 8, 3, 338-353, 1965.

[24] Zimmermann H., Fuzzy Sets Theory and Its Applications, 2nd ed. Boston (MA): Kluwer Academic Publishers, 1991.

[25] Santarek K., Baginski J., Buczacki A., Sobczak D., Szerenos A., Building Mechanism of Technology Transfer From University to Business [in Polish: Tworzenie Mechanizmów Transferu Technologii], Warszawa: PARP, 2008.

[26] Eversheim W. [Ed.], Innovation Management for Technical Products, Berlin: Springer, pp. 175-188, 2009 .

[27] Mehrjerdi Y.Z., Group decision making process for RFID-based system selection using fuzzy TOPSIS approach, Artif. Intell. Res., 2, 3, 1-15, 2013, DOI: 10.5430/air.v2n3p1. 
[28] EPCglobal, EPC $C^{T M}$ Radio - Frequency Identity Protocols Generation-2 UHF RFID Specification for RFID Air Interface Protocol for Communications at $860 \mathrm{MHz}-960 \mathrm{MHz}$ Version 2.0.1, 2015, http://bit.ly/1FiSkLw, accessed: 5 June 2015.

[29] GS1, GS1 Identification Keys in Transport and Logistics, 2013, http://tinyurl.com/nbnoorq, accessed: 2 June 2015.

[30] GS1, GS1 Standards for Delivery Management, 2015, http://tinyurl.com/q2mf9kw, accessed: 2 June 2015.

[31] SAP, Flexible Delivering Processing, 2015, http://tinyurl.com/ngubrvk, accessed: 4 June 2015.

[32] Veeramani D., Tang J., Gutierrez A., A framework for assessing the value of RFID implementation by tier-one suppliers to major retailers, J. of Theor. and Appl. Electron. Commer. Res., 3, 1, 55-70, 2008, http://tinyurl.com/ocfg3cc, accessed: 4 June 2015 .

[33] Hryniewicz O., Fuzzy set membership function - design and interpretation methods [in Polish: Funkcja przynależności zbioru rozmytego - metody konstrukcji $i$ interpretacji], Studies of Polish Associa- tion of Knowledge Management (in Polish: Studia i materiały PTZW), 31, 31, 8-17, 2010.

[34] Gladysz B., RFID technology markets in Poland [original in Polish: Rynki technologii RFID w Polsce], in Ekonomika i Organizacja Przedsiebiorstw, 7, 32-4, 20121.

[35] Gladysz B., RFID technology markets in Poland (2014), [original in polish: Rynki technologii RFID $w$ Polsce (2014)], Ekonomika i Organizacja Przedsiebiorstw, 5, 45-56, 2014.

[36] Nathanson A., Managed Services: RFID'S Newest Deployment Method and Business Model, A Research Note, AutoID \& Transaction Automation Practice, VDC Research Group, September 2009, http://tinyurl.com/jrc3yqj, accessed: 5 September 2016 .

[37] Bensel P., Vogeler S., Tröger R., RFID-based Business Models - A Case Study from the Textile Industry, Frank Straube (Hrsg.), Digitale Schriftenreihe Logistik Technische Universität Berlin, Universitätsverlag der Technischen Universität Berlin, 2009, http://tinyurl.com/glckmd3, accessed: 5 September 2016. 